\title{
The Status of Streamflow and Ground-Water-Level Monitoring Networks in Maryland, 2005
}

by James M. Gerhart (U.S. Geological Survey) and Emery T. Cleaves (Maryland Geological Survey)

\section{Abstract}

The monitoring of streamflow and ground-water levels in Maryland is vitally important to the effective management and protection of the State's water resources. Streamflow and ground-water-level monitoring networks have been operated for many years in Maryland, and in recent years, these networks have been redesigned to improve their efficiency. Unfortunately, these networks are increasingly at risk due to reduced and fluctuating funding from Federal, State, and local agencies. Stable, long-term funding is necessary to ensure that these networks will continue to provide valuable water data for use by State and local water-resources managers.

\section{The Importance of Water in} Maryland

Water is one of the most valuable natural resources in

Maryland. It is essential to the life and health of all Maryland residents, the quality of the State's environment, and the vitality of its economy. In 2000, Marylanders used an estimated 1.45 billion gallons per day of freshwater for public supply, commercial, industrial, irrigation, and other purposes (Wheeler,
2003). Although there usually is more than enough water to meet that level of water demand, periodic droughts like the ones in the early 1930s, the mid1960s, 1999, and 2002 can cause serious water shortages in some parts of the State. As the population of

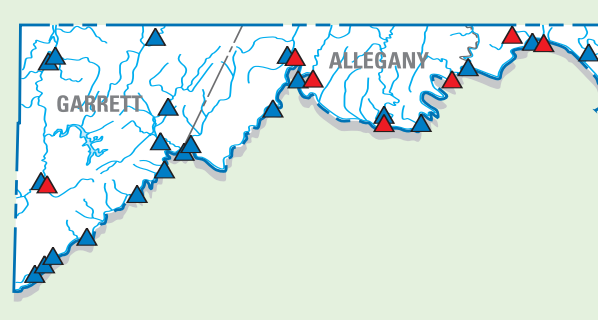

EXPLANATION

$\triangle$ ACTIVE STREAM GAGE

$\triangle$ PROPOSED STREAM GAGE
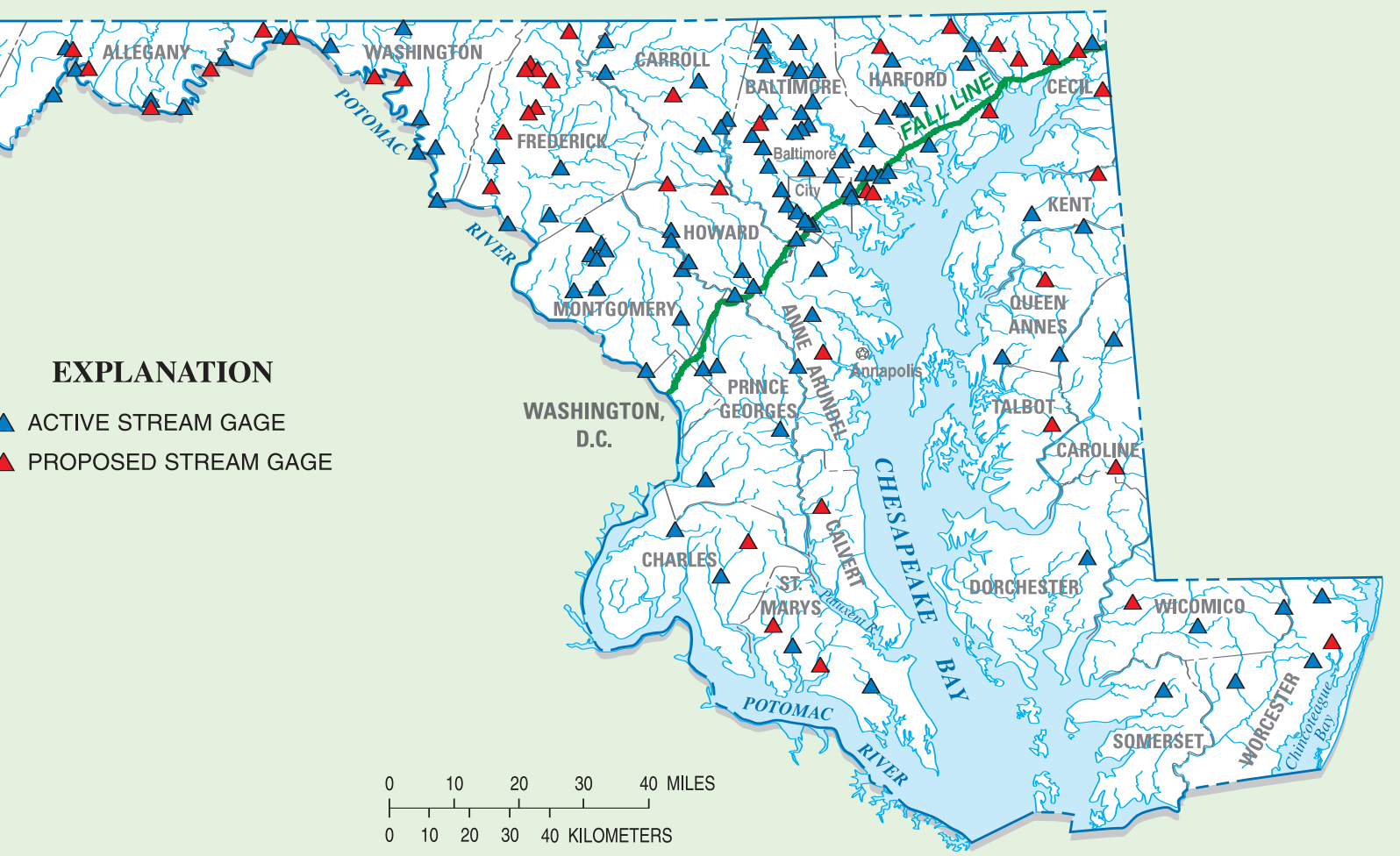

Figure 1. The optimal streamflow-monitoring network in Maryland, showing the 119 current (2005) stream gages, and the 43 recommended additional stream gages needed to reach the optimal network design. 


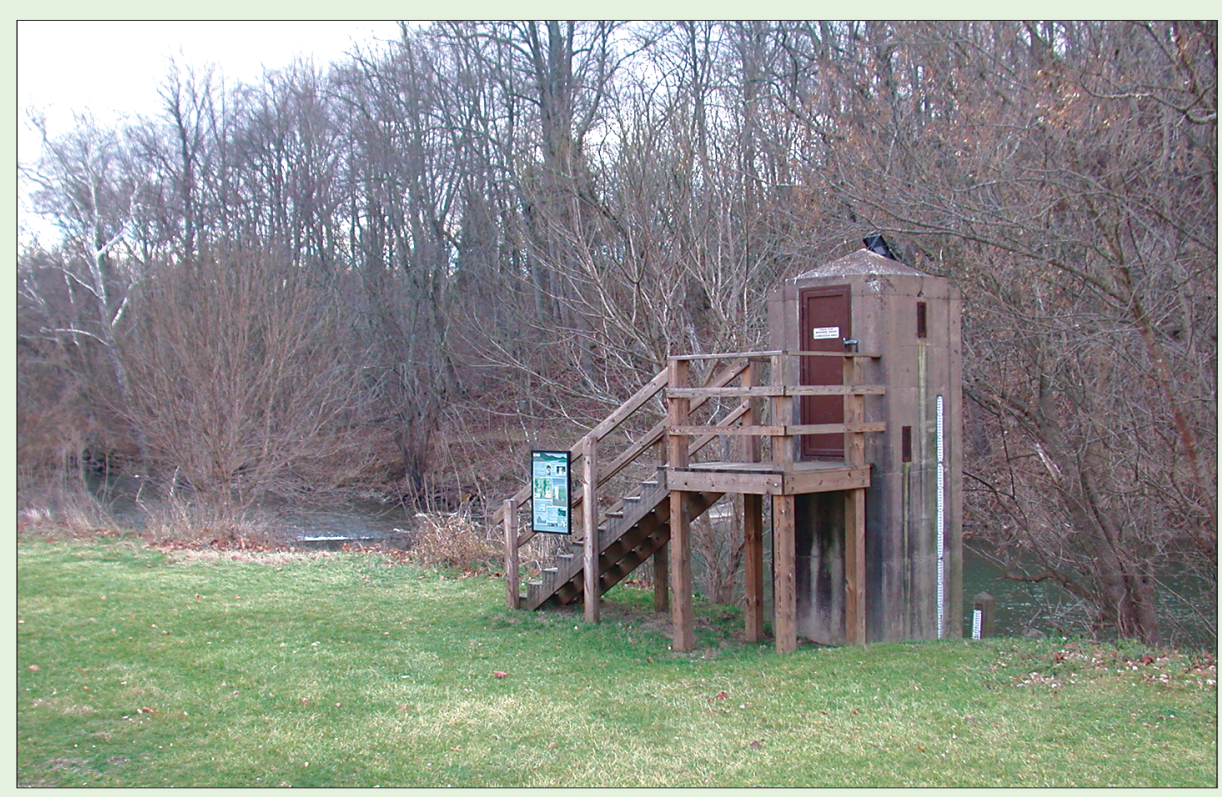

Stream gage 01619500 on Antietam Creek near Sharpsburg, Maryland, in Washington County. (Photograph by Charles J. Strain, USGS)

Maryland and the demand for water continue to increase, water shortages are expected to become more common. Long-term planning for the efficient use of Maryland's water resources is critical for avoiding major water shortages in the future.

\section{The State Advisory Committee Report}

The Governor's Advisory Committee on the Management and Protection of Maryland's Water Resources was established in late 2003 to map out a long-term plan for managing and protecting the State's water resources. In August 2004, the Committee released a report (State of Maryland, 2004) containing numerous recommendations, including one for maintaining and enhancing the monitoring of Maryland's water resources. The Committee's report recognized that without adequate monitoring data, "...it will become difficult or impossible to determine the availability of surface water or ground water, to assess and react to droughts, to determine the potential interference of competing water users, and to assess the impacts of water use on the State's aquifers and streams, while maintaining minimum stream flows" (State of Maryland, 2004).

\section{Two Major Water-Monitoring Components}

Two critical components of waterresources monitoring in Maryland are the monitoring of streamflow and the monitoring of ground-water levels. Maryland is fortunate to have a long history of streamflow and ground-waterlevel monitoring. Streamflow in most major streams in the State has been monitored for about the last 50-100 years, and ground-water levels in most major aquifers in the State have been monitored for about the last 50 years. Both of these long-term monitoring programs have been operated primarily by the U.S. Geological Survey (USGS), in partnership with the Maryland Geological Survey (MGS), and with the financial support of many other Federal, State, and local agencies.

\section{Streamflow Monitoring Network}

Currently (2005), the USGS operates 119 streamflow-monitoring gages in Maryland (fig. 1). Stream stage is monitored at each gage every 15 minutes. Streamflow is calculated from stream stage through the use of rating curves that have been developed over time and frequently updated.

Streamflow data for 83 of 119 gages are available in near real time on the USGS website

(http://waterdata.usgs.gov/md/nwis/rt). All streamflow data are reviewed and published annually, and are available on the USGS website. A streamflow hydrograph for Deer Creek at Rocks, Maryland, for the period October 1, 1998 through September 30, 2003, is shown in figure 2; the hydrograph illustrates the low streamflows during the

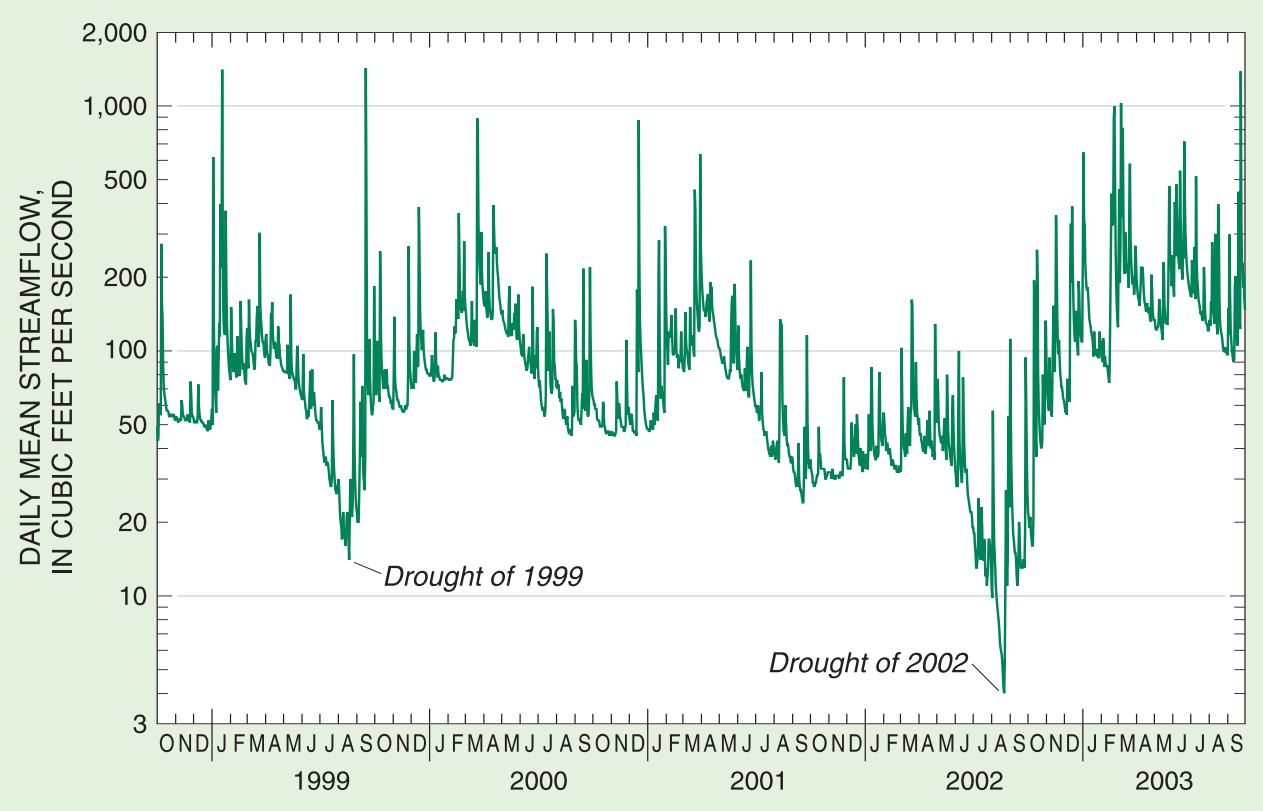

Figure 2. A 5-year streamflow hydrograph for the stream gage at Deer Creek at Rocks, Maryland. Note the low streamflows during the 1999 and 2002 droughts. 
droughts of 1999 and 2002.

Streamflow data are used by many Federal, State, and local agencies in Maryland. Some of the many uses of streamflow data include: (1) water-supply assessment; (2) watershed management; (3) stream restoration; (4) bridge design; (5) flood warning; (6) sediment and contaminant loading; and (7) recreational activities. The principal funding agencies for the Maryland streamflowmonitoring network are USGS, MGS, Maryland State Highway Administration, U.S. Army Corps of Engineers,

Maryland Department of the

Environment, Maryland Department of Natural Resources, Baltimore County, and Baltimore City.

The number of Maryland's streams that are monitored each year depends on the availability of funding. In 1996, the number of gages in Maryland totaled only 75 , the lowest number in recent years (fig. 3). In the late 1990s, as a result of an interagency workshop and a concerted effort by many agencies working together through the Maryland Water Monitoring Council, a report that presents a design for an optimal gage network in Maryland was published (Cleaves and Doheny, 2000). As a direct result of that effort, as well as the reaction to the droughts of 1999 and 2002, the number of gages had risen to 110 by 2002 . By the beginning of 2005, the number of gages was 119 (fig. 3).

Even though the number of gages has increased fairly steadily over the last decade, the number of long-term (greater than 50 years of record) gages threatened by funding shortages has been increasing in the last few years. A threatened gage is sometimes "saved" at the last minute by funding from an interested Federal, State, or local agency. In some cases, however, a gage is discontinued when replacement funding is not available. Stable, longterm funding would guarantee the continuation of these especially valuable long-term gages, as well as the gage network as a whole.

The Advisory Committee's report (State of Maryland, 2004) suggests that all currently operating gages be maintained with stable, long-term funding to prevent breaks in the long-term continuous records at the monitoring sites. In addition, the report recommends that gages be added on 43 other streams in Maryland as funds allow, for the purposes of addressing unmet small-watershed, core-network, and geographiccoverage needs. The desired complete network of gages would provide the data needed to make sound management and protection decisions for all important streams and watersheds in the State.

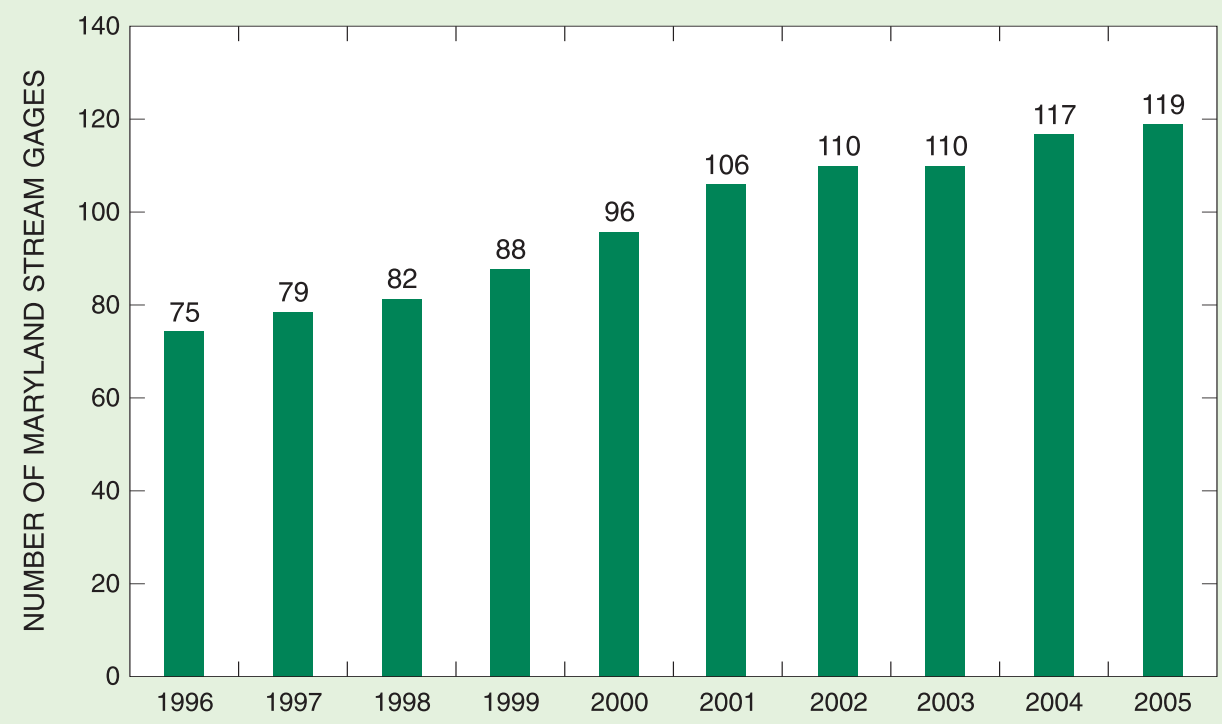

Figure 3. The number of Maryland stream gages during 1996-2005. Note the steady increase, which is attributed to the efforts of the Maryland Water Monitoring Council and the reaction to the droughts of 1999 and 2002.

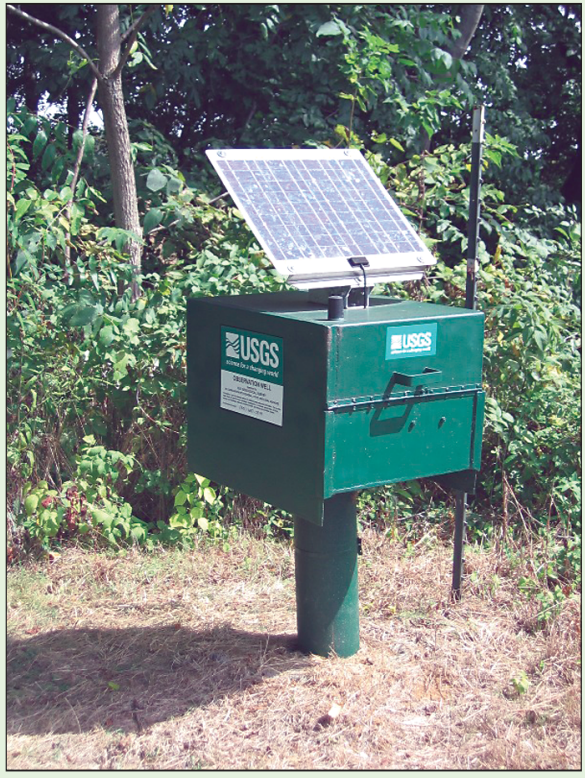

Observation well WA Ci 82 in Washington County, Maryland, with near-real-time transmission equipment. (Photograph by Charles J. Strain, USGS)

\section{Ground-Water-Level Monitoring Networks}

Ground-water-level data provide one of the only direct measures of the health of Maryland's aquifers. Groundwater-level data are used by many Federal, State, and local agencies to: (1) discern long-term trends; (2) provide drought warning and tracking; and (3) inform the State's ground-water appropriation permitting process. The funding agencies for Maryland's large-scale ground-water-level networks are USGS and MGS. Other smaller networks are operated by USGS and MGS for specific local purposes, and are supported by the Interstate Commission on the Potomac River Basin, Calvert County, Charles County, Anne Arundel County, and other local jurisdictions.

The USGS and MGS measure ground-water levels in aquifers in Maryland for two primary purposes. The water table in the fractured-rock and unconsolidated-sediment aquifers is monitored statewide for the effects of climate variability; the water levels in the confined unconsolidated-sediment aquifers of the Atlantic Coastal Plain are monitored for the effects of ground- 
water pumpage (M.T. Duigon, Maryland Geological Survey, written commun., 2004). In each network observation well, water level is either measured by hand using an electric tape, or continuously using an automated logging device. Nine wells are equipped with near-real-time capability.

Under the auspices of the Maryland Water Monitoring Council, a multi-agency workshop was convened in June 2002 to begin the process of redesigning the ground-water-level monitoring networks for Maryland. By 2004, new optimal designs had been adopted for both the water-table-aquifer and the confined-aquifer observationwell networks.

\section{Water-Table-Aquifer Network}

The first of the two ground-waterlevel networks in Maryland-the watertable-aquifer network (fig. 4)-ideally would include 81 observation wells and is designed to capture the effects of precipitation on ground-water levels in key topographic settings in all major physiographic and geologic units in Maryland. In the fractured-bedrock aquifers west of the Fall Line, most wells would be paired, with one in the bedrock and one in the weathered material above the bedrock; in the unconsolidated-sediment aquifers east of the Fall Line, single wells would be used (fig. 4). Water-level data from this network would be used to track the progress of droughts and subsequent recovery from them, and would be used by the State as a guide for imposing drought-related water restrictions on a regional basis. The water-level hydrograph in figure 5 covers a 5-year period from October 1, 1998 through September 30, 2003 for well MO Eh 20 in Montgomery County, and shows the low water levels during the droughts of 1999 and 2002.

Unfortunately, the optimal watertable-aquifer network currently is not complete. Water levels have been measured in 30 of the 81 wells for many years, but 51 additional wells are needed to complete the network and fully represent all the key topographic settings in the major hydrogeologic units in Maryland. The Advisory Committee's report (State of Maryland, 2004) recommends that all current wells be maintained and that the additional needed wells be added as funding permits.

\section{Confined-Aquifer Network}

The second of the two groundwater-level networks in Maryland-the confined-aquifer network-is designed to capture the effects of ground-water pumpage, and ideally would include 159 observation wells in the seven most important aquifers in Maryland's Coastal Plain (the Chesapeake Group, Piney Point-Nanjemoy, Aquia, Magothy, upper Patapsco, lower Patapsco, and Patuxent aquifers). The optimal network for one of these aquifers, the Aquia, is shown in figure 6 and indicates the number of wells that are currently being monitored and the number of additional wells needed to meet the optimal network design. Similar optimal

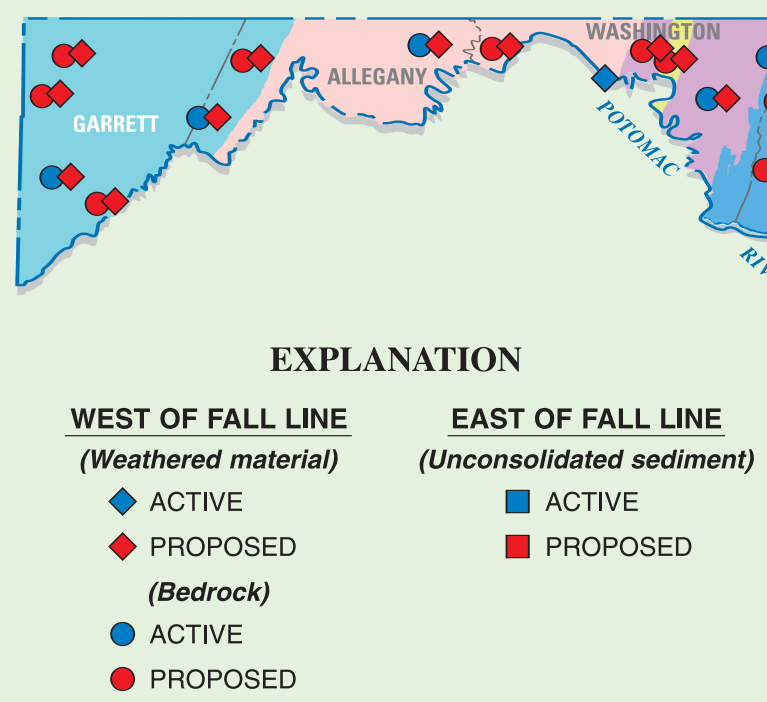

PHYSIOGRAPHIC PROVINCES

APPALACHIAN PLATEAU

FOLDED APPALACHIANS HAGERSTOWN VALLEY CARBONATES HAGERSTOWN VALLEY SHALES BLUE RIDGE MESOZOIC LOWLANDS
PIEDMONT CARBONATES PIEDMONT UPLANDS NON-CARBONATES WESTERN SHORE COASTAL PLAIN UPLANDS WESTERN SHORE COASTAL PLAIN LOWLANDS EASTERN SHORE COASTAL PLAIN UPLANDS EASTERN SHORE COASTAL PLAIN LOWLANDS

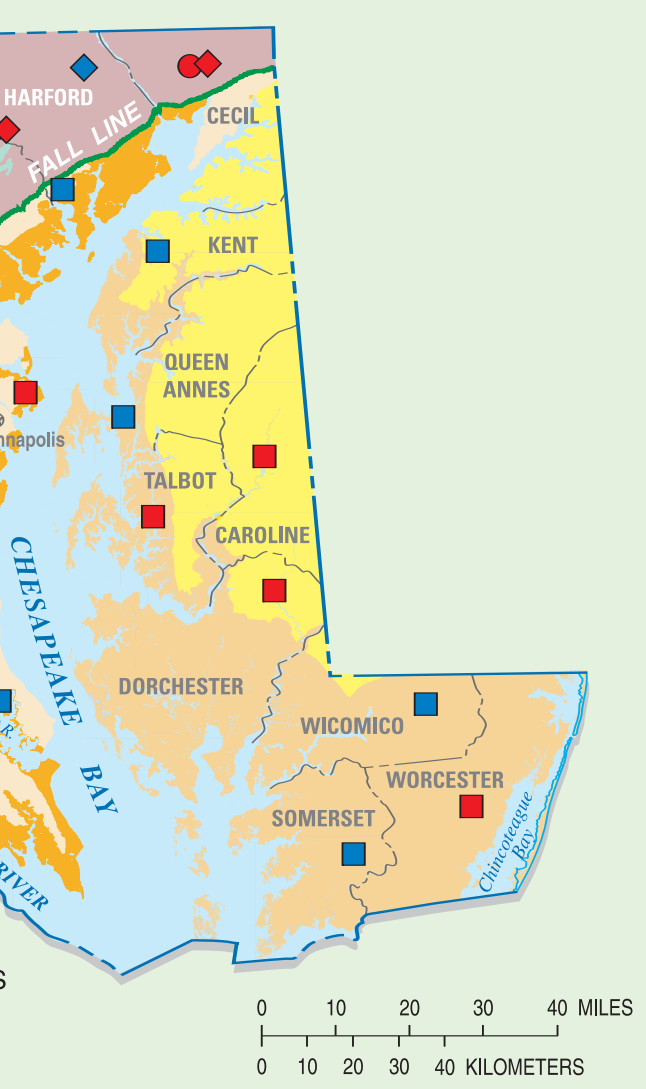

Figure 4. The optimal water-table aquifer, observation-well network in Maryland, showing the 30 current (2005) observation wells, and the 51 recommended additional observation wells needed to reach the optimal network design (modified from M.T. Duigon, Maryland Geological Survey, written commun., 2004). 


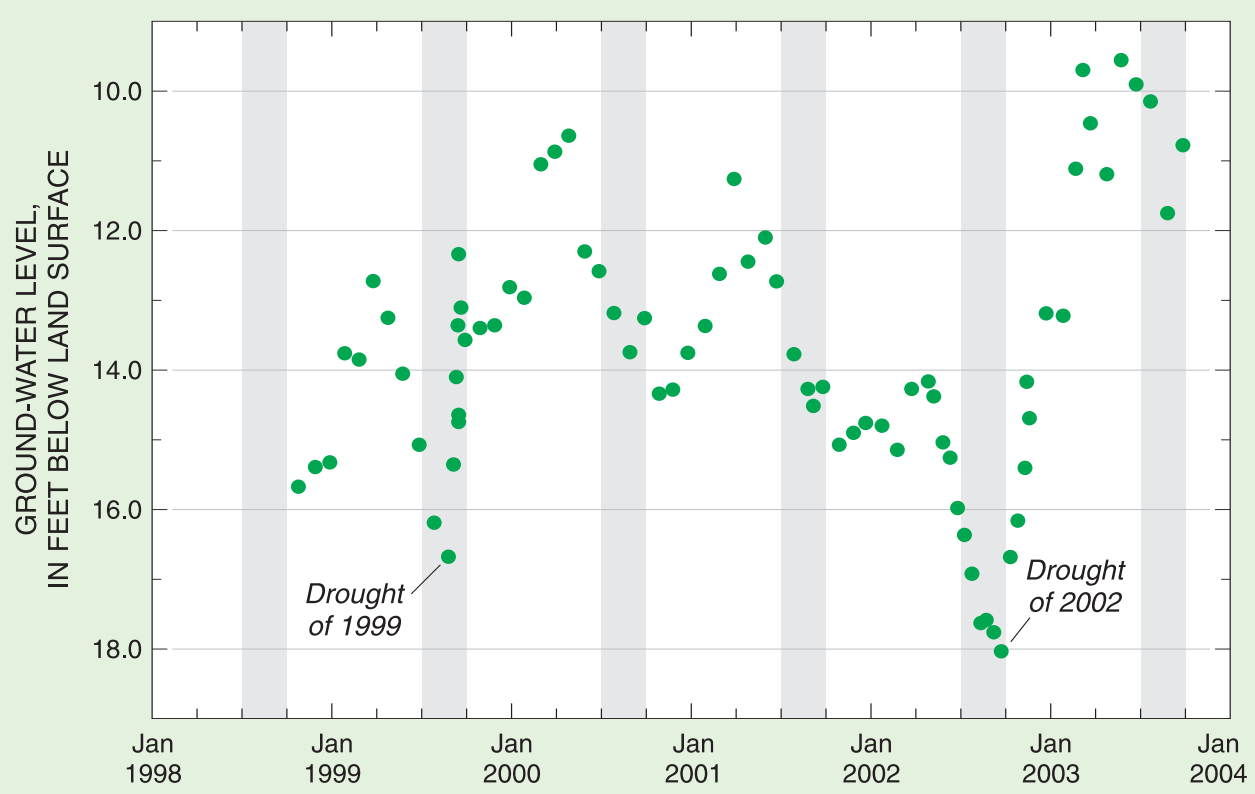

Figure 5. A 5-year ground-water-level hydrograph for water-table-aquifer observation well MO Eh 20 in Montgomery County, Maryland, showing seasonal variations in ground-water levels and the low levels during the droughts of 1999 and 2002. (Gray bars indicate July-October of each year.)

networks have been designed for each of the other six major Coastal Plain aquifers.

As ground water is pumped from these confined aquifers, the pressure in the aquifers decreases, causing water levels in observation wells to decline. A water-level hydrograph for an observation well (CA Gd 6) in the Aquia aquifer near Solomons in Calvert County, where the water level has been declining since the 1960s due to groundwater pumpage, is shown in figure 7 . The hydrograph shows that the rate of decline increased significantly in the mid-1980s, with the total decline over the past 45 years being about 120 feet. The amount and rate of water-level decline are valuable indicators used in determining the availability of ground water to meet future demands from each of these aquifers.

As is the case with the water-tableaquifer network, the confined-aquifer network is also incomplete. The current observation-well networks for all seven major Coastal Plain aquifers consist of 110 observation wells, but 49 additional wells are needed to complete the networks as designed and to provide all the necessary data to support sound ground-water allocation decisions for all areas in Maryland where the seven major confined aquifers are present. The Advisory Committee's report (State of Maryland, 2004) recommends maintenance of the current number of observation wells and the addition of new wells, including drilling when necessary, as funding permits.

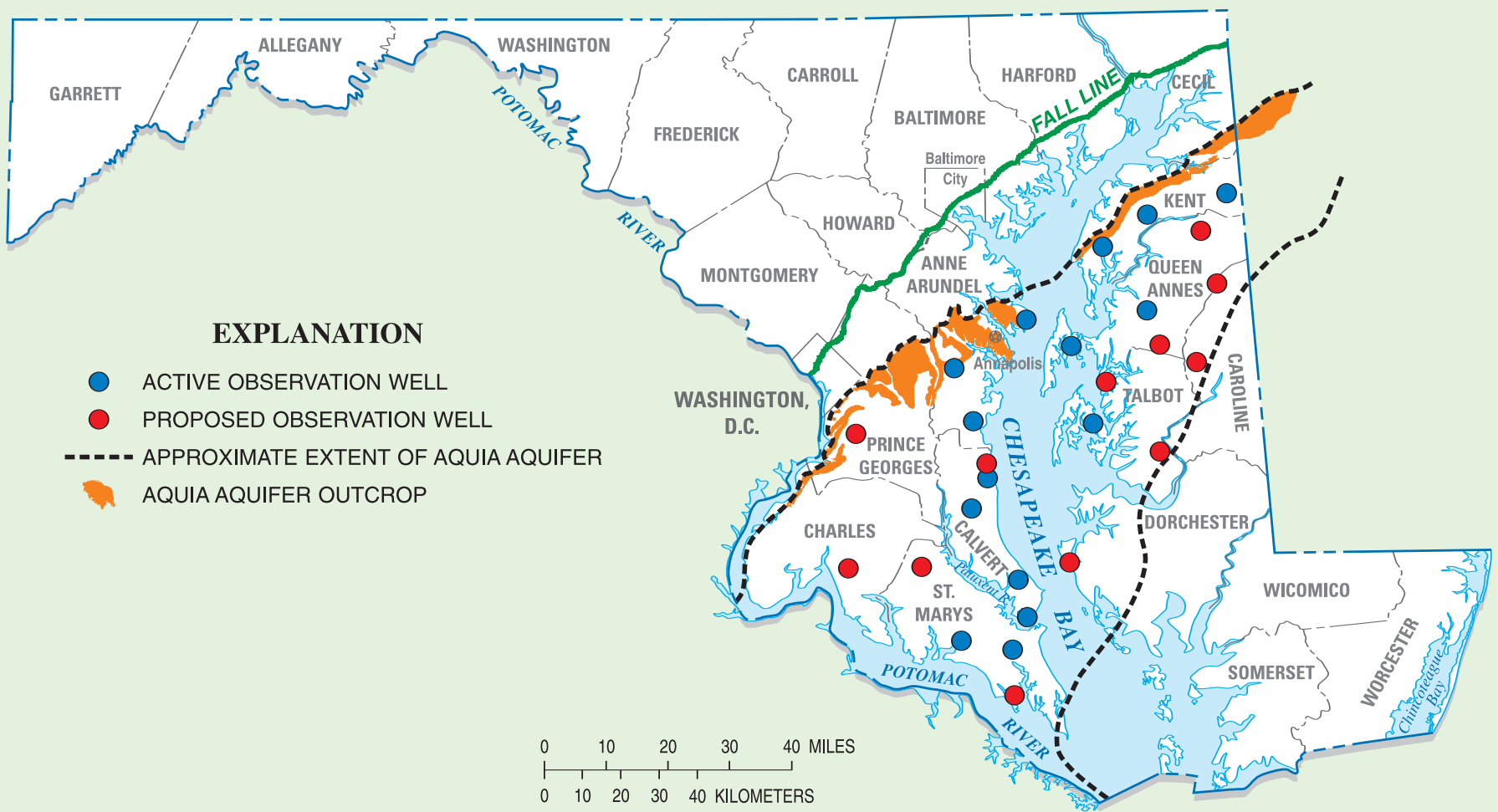

Figure 6. The optimal confined-aquifer, observation-well network in Maryland's Aquia aquifer, showing the 15 current (2005) observation wells, and the 12 recommended additional observation wells needed to reach the optimal network design for the Aquia aquifer. 


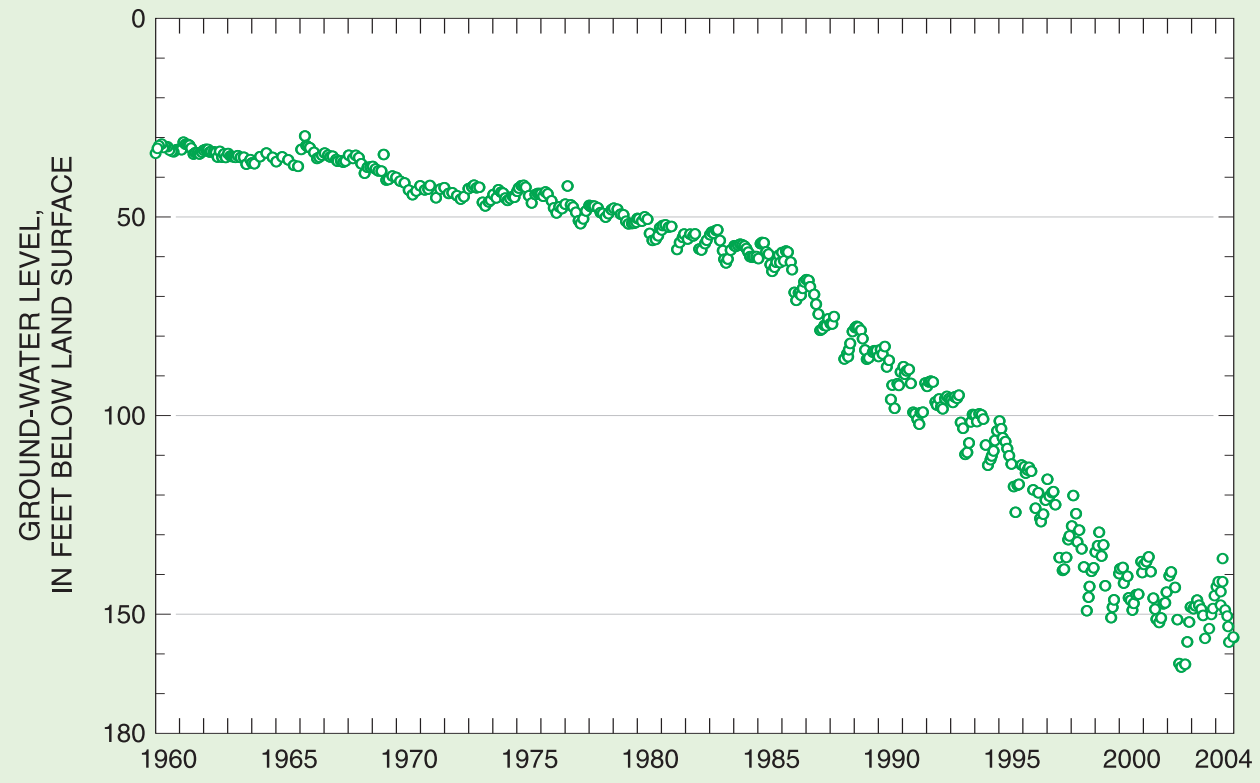

Figure 7. A 45-year ground-water hydrograph for confined-aquifer observation well CA Gd 6 near Solomons in Calvert County, Maryland, showing the declining water levels due to ground-water pumpage. Note the significant increase in rate of decline in the mid-1980s.

\section{Summary}

Monitoring of streamflow and ground-water levels in Maryland is necessary for the sound management and protection of the State's water resources. Numerous Federal, State, and local agencies support the current monitoring efforts, and use the streamflow and ground-water-level data to inform many important decisions being made in Maryland. The Advisory Committee on the Management and Protection of Maryland's Water Resources strongly supports the continuation and enhancement of streamflow

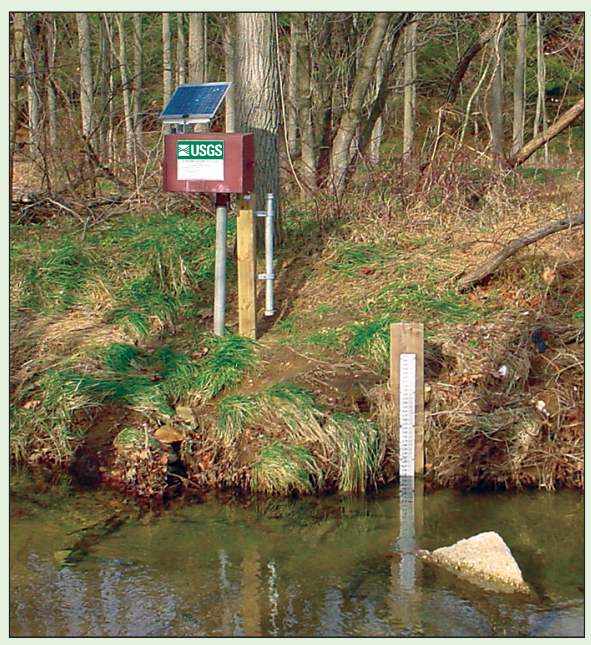

Stream gage 0158397967 on Minebank Run near Glen Arm, Maryland, in Baltimore County. (Photograph by Michael A. Hansen, USGS) and ground-water-level monitoring in Maryland. Long-term data on streamflow and ground-water levels are readily available on the U.S. Geological Survey website, and optimal networks for streamflow and ground-water-level monitoring have been designed through multi-agency efforts. The full implementation of the optimal networks, which will supply the water data necessary to provide sound and efficient waterresources management and protection decisions, depends on adequate funding from Federal, State, and local agencies. Stable, long-term funding support is needed to guarantee that streamflow and ground-water-level data are available when needed.

\section{References Cited}

Cleaves, E.T., and Doheny, E.J., 2000, A strategy for a stream-gaging network in Maryland: Maryland Geological Survey Report of Investigations No. 71, 72 p.

State of Maryland, 2004, Advisory Committee on the Management and Protection of the State's Water Resources, Final Report: [variously paged.]

Wheeler, J.C., 2003, Freshwater use trends in Maryland, 1985-2000: U.S. Geological Survey Fact Sheet 112-03, 4 p.

\section{Additional Information}

For further information, please contact: District Chief, MD-DE-DC District U.S. Geological Survey 8987 Yellow Brick Road Baltimore, Maryland 21237

or visit the Maryland-Delaware-District of Columbia District homepage on the World Wide Web at: http://md.water.usgs.gov

To access near-real-time streamflow data for Maryland, visit: http://waterdata.usgs.gov/md/nwis/rt

For information about the Maryland Department of Natural Resources, visit: http://www.dnr.state.md.us

To learn more about the Maryland Water Monitoring Council, visit: http://www.mgs.md.gov/mwmc

Editor: Valerie M. Gaine

Graphics and design: Timothy W. Auer

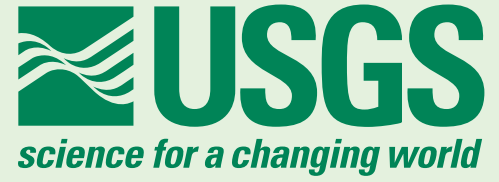

USGS Fact Sheet FS 2005-3030 